\title{
Effect of an Educational Program on Healthy Use of Mobile Phone among Faculty of Nursing Students
}

\author{
Dr. Soha Kamel Mesbah ${ }^{1}$ and Dr. Mervat Amin Sayed ${ }^{2}$ \\ ${ }^{1}$ Department of Community - Faculty of Nursing - Benha University-Egypt \\ ${ }^{2}$ Department of Community - Faculty of Nursing - Fayoum University-Egypt
}

\begin{abstract}
Mobile phones, used especially among university students for variety of purposes, can also have negative effects on the user's health.

Aim: The study aimed to evaluate effect of an educational program on healthy use of mobile phone among Faculty of Nursing students, El Fayoum University.

Design: A quasi experimental design was used in this study.

Setting: This study was conducted in the Faculty of Nursing, El Fayoum University.

Sample: A purposive sample of 177 students in the Faculty of Nursing was recruited.

Tool: An interviewing questionnaire for the assessment of students' knowledge about the mobile phone, uses of mobile phone in academic and nonacademic activities and students' practices as stated by them regarding mobile phone healthy use

Results: The study noted that there were statistically significant differences between students' knowledge about meaning of cell phone, function of cell phone, type of cell phone radiation, the distance between the cell phone and the eye, changes of cell phone on the body, effects of radiation from cell phone, effects of electromagnetic waves, effects of sleeping near to a cell phone and effects of long term use throughout the program as well, between their practices regarding receiving calls, during communication, carrying a cell phone and using multimedia throughout the program. However, there was statistically insignificant difference between impacts of cell phone on social aspects on the studied subjects throughout the program.

Conclusion: The results concluded that, there was significant improvement in the students' knowledge regarding healthy mobile phone use, healthy practices of mobile phone as they sated at the post test compared with pretest, while there was an insignificant improvement related to effects of mobile phone on the Faculty of Nursing students.

Recommendations: More studies in this field are urgently needed with large probability sample from different geographical areas to allow greater representation and generalization of the results, to develop health education programs for students about effects of mobile phone

Keywords: Cell Phone, Mobile, Knowledge, Healthy Use Practices, Effects of Mobile Phone.
\end{abstract}

\section{Introduction}

As cell phones have become more available, they are increasingly owned and used by teens. Further, as handsets become more loaded with capabilities ranging from video recording and sharing, to music playing and internet access, teens and young adults have an ever-increasing repertoire of use. Indeed, they are moving into an era when mobile devices are not just for talking and texting, but can also access the internet and all it has to offer (North et al., 2014).

The usefulness of cell phones is numerous and this includes keeping contact with friends, members of the family, conducting business and others. Many people possess more than one mobile phone for different purposes, which could be for business purpose or personal purpose. A number of people are also taking the advantage of multiple SIM cards for benefit of different calling plans since a calling plan might provide cheaper local calls, long-distance calls, international calls, or roaming (King et al., 2014).

According to Bhise et al. (2014), the impacts of mobile phone technologies on learning are portability, collaboration and motivation enhancing students, parents and teachers' education system. The mobile phone portability enables student learning to be ubiquitous in obtaining or retrieving course information through their mobile phones as they are carried from class to class or wherever. Their portability can improve a wide variety of learning settings, namely a field trip, the classroom, or outside the campus. Collaboration social networks such as Facebook and Twitter accessed on students' mobile phones allow students to form groups to distribute and add together their knowledge, and share information with ease, and this could result in a more successful collaborative learning as highlighted by Beniwal and Sharma (2013).

According to classification of adolescent period, university students are in age from 18-24 years, they are considered in late adolescent. University students are the most frequent users for mobile phones compared 
to all other age groups. Health status in this age group is also important for the future health (Nehra et al., 2012).

Mobile phones have powerful Electromagnetic radiations (EMRs). It communicates by transmitting radio waves through a network of fixed antennas called base stations. Radiofrequency waves are electromagnetic fields, and unlike ionizing radiation such as X-rays or gamma rays, can neither break chemical bonds nor cause ionization in the human body (WHO, 2011). Over usage of mobile phones leads to physiological health hazards like headaches, ear aches, warmth sensation, fatigue and musculoskeletal symptoms. Apart from the various benefits of cell phone, its over usage leads to mobile phone addiction. It is one of the biggest non drug addictions in the world (Hakoama \& Hakoyama, 2011). The World Health Organization confirmed that mobile phone use may represent a long-term health risk, classifying mobile phone radiation as a "carcinogenic hazard" and "possibly carcinogenic to humans" after a team of scientists reviewed peer-review studies on cell phone safety. One study of past cell phone use cited in the report showed a "40\% increased risk for brain cancer in the highest category of heavy users (Ames, 2013).

Mobile phone has many bad effects on human's life. These effects are not only physical but also social and economical. First, like different addictions, it can render the addicts insensitive to the impact of their behavior on others around them. mobile phone addicts often can be seen shouting into their phones in crowded public environments, noisily disrupting everybody close, when they may easily have waited a couple of minutes to receive call or call back when shopping or eating (WHO, 2006).

Far worse, young car, motorcycle, and bicycle drivers are often seen driving with one hand, while talking into a mobile control with the other. This practice is very dangerous, as a result of utilizing a mobile may distract the driver's attention - long enough to possess an accident like different addictions, cell phone addiction may fragment the mind and behavior of the addict (Kuznekoff \& Titsworth, 2013). Frequent interruption by mobile use can disrupt normal thought processes, and significantly those that need consideration. Likewise, addictive use of mobile phones can become a replacement within the addict's life for alternative additional necessary activities - like reading, face-to-face meeting, finding personal issues, serious thinking, or different meaningful activities (Arif \& Aslam, 2014).

Behavioural addiction for mobile phones has been variously termed as Mobile Phone Dependence, Mobile Phone Problematic Use, Problem Cell Phone Use, and Mobile Phone Abuse. The symptoms include preoccupation with the device, excessive use with loss of control, use in socially inappropriate/dangerous situations, adverse effects on relationships, symptoms of withdrawal, symptoms of tolerance, and functional/behavioral impairments (Nehra et al., 2012).

Health educational program is an intervention by which nursing students learn to behave in a manner conducive to promote, maintain, or restore health, and encourage them to make change in their personal use of mobile phone; it includes providing information, motivation and persuasion for improving knowledge, and developing life skills which are conducive to individual and community health (Wikipedia, 2015).

Community health nurses are the primary care providers, working in an expanded nursing role with other health care professionals. Community Health Nurse is to provide community health promotion services in a designated region in accordance with the philosophy and objectives of the authority and to promote the prevention of disease, maintenance of health and the overall health and wellbeing of the community (Diem \& Moyer, 2015).

Significance of the study:

The invention of technology such as mobile phones has, no doubt, brought about immense positive progress to human societies, but this invention equally brought in its wake some observed attitudinal problems among university students. However, this is not to say that these problems are solely caused by the usage of these phones as there are other causes, but that the attitudes of the users and the modes of the usages are significantly the contributing factors especially in the $21^{\text {st }}$ century (Merlo et al., 2013). According to recent studies foundation, university students have increased the amount of time they use mobile multimedia more than 7 hours a day. The university students use it seven days a week so, more than 50 hours a week will be spent in front of mobile phone. Increasing time they spend in front of mobile phone lead to increasing exposure to health effects (Shinde \& Patel, 2014).

The use of mobile phones has affected the youth to a large extent. Since it has become an unavoidable part of life. Technology is enhancing day by day. And therefore dependency on mobile phones is increasing due to its unique features. Mobile phones are not considered as a device for communication alone but it is 
Effect of an Educational Program on Healthy Use of Mobile Phone among Faculty of Nursing ..

considered as a media for entertainment. Also the use of mobile phones has enhanced e-learning but on the other hand, it has affected school premises by creating disturbances. Prolonged mobile phone use has been associated with dependency on the mobile phone leading to many physical effects (Beniwal \& Sharma, 2013). Also, overuse has been associated with somatic complaints, anxiety, and insomnia, depression, and an unhealthy lifestyle. Studies have shown that people who sleep with a mobile phone near the bed have sleep problems, leading to impaired academic achievement and memory (Thomee et al., 2011).

\section{Aim of the study}

This study aims to evaluate the effect of educational program on healthy use of mobile phone among faculty of nursing students through:

1. Assessing nursing students' needs about healthy use of mobile phone.

2. Designing and carrying out an educational program to faculty of nursing students based on the previously detected needs.

3. Evaluating the degree of improvement of educational program on nursing students' knowledge and practices on healthy use of mobile phone.

\section{Research Questions:}

1. What are the nursing students' knowledge and practices to detect their educational needs?

2. What are the effects of mobile phone use on their health?

3. What is the effect of health educational program to faculty of nursing students' knowledge and practices on healthy use of mobile phone?

\section{Subjects and Methods}

The subjects and methods of the current study were discussed under the following four designs:

I. Technical Design

a- Research Design: A quasi-experimental design was used in carrying out this study.

b- Study Setting: The study was conducted in the Faculty of Nursing, El Fayoum University.

c- Sample: A purposive sample used in this study composed 177 students enrolled at the Faculty of Nursing in El Fayoum University regardless of their residence, age, gender, etc., They were selected according to a random technique, 1 st year: Total number of students is $(300) 10 \%(30)$ students, $2^{\text {nd }}$ year: Total number of students is (130) $40 \%$ (52) students, $3^{\text {rd }}$ year: Total number of students is (367) $10 \%$ (36) students and $4^{\text {th }}$ year: Total number of student is (85) $70 \%$ (59) students were chosen.

d- Tool of data collection: An interviewing questionnaire, the researcher designed questionnaire based on literature review, and written in simple Arabic language consisted of five parts as the followings:

$1^{\text {st }}$ part: it was designed to collect data about personal and educational characteristics of students. It included questions about gender, age, grade, rank, and residence.

$2^{\text {nd }}$ part: it concerned with mobile phone uses in academic and nonacademic activities such as; access sites related to nursing, read lecture notes, shop on the internet, and Play online games.

$3^{\text {rd }}$ part: it was devoted to assess student's knowledge about the mobile phone. The questions covered areas such as, meaning, uses, waves emitted from it, distance between the cell phone and the eye, and effect of waves on visual and auditory organ. (pre - posttest format).

Scoring system for knowledge items: correct answered were predetermined according to literature review; a correct answer was scored one, and the incorrect answer was scored zero. These scores were summed-up and converted into a percent score: from 0 - <60 referred to unsatisfactory knowledge while score from $60 \leq 100$ referred to satisfactory knowledge.

4th part: it was designed to assess student's practices as stated by them regarding mobile phone healthy use, it was adopted from Ibrahiem (2016), and it included the following; Receiving calls, during communication, and carrying a cell phone (Pre - posttest format).

Scoring system for student practices regarding healthy use of mobile phone: Always used was scored two, sometimes used was scored one and never used was scored zero. These scores were summed-up and converted into a percent score: from $0<75$ referred to unsatisfactory practices, while score from $75-\leq 100$ referred to satisfactory practices.

5th part: it was concerned with effects of mobile phone on faculty of nursing students, it was adopted from Ibrahiem (2016), and it consisted of three items: 
i. The physical effect of mobile phone use on faculty of nursing students as whether she feels headache, blurred vision, muscle weakness, memory loss, loss of concentration and sleep disturbance

ii. social effect of mobile phone on faculty of nursing students as; lost time, feel happy when you connect with others, unable to control of self when lost mobile .

iii. Economical effect of mobile phone on faculty of nursing students as requiring a lot of money for calls needs a lot of money in maintenance.

Scoring system for effects of mobile phone: The "always used" was scored two, "sometimes used" was scored one and "never used" was scored zero. These scores were summed-up, converted into a percent score and evaluated as follows: from $0-<75$ referred to low/no effect, while score from $75-\leq 100$ referred to sever effect.

\section{Reliability and content validity of the tools:}

The tool was tested for reliability it was 0.89 by Cronbach's alpha and validity by 3 juries one who are expert in the community health nursing and 2 experts in mobile phone electromagnetic field.

\section{Operational Design: Pilot Study:}

The pilot study was carried out on $10 \%$ of the sample. They were chosen randomly to test the content, applicability, clarity, and simplicity of the tool using the interviewing questionnaire as a pre-test sheet. Those who shared in the pilot study were excluded from the studied sample based on the pilot results, the tools were modified. Modification of the tool included rephrasing and rearrangement of some questions. After refinement and modification, the final forms of the tool were developed. This pilot study was carried out in two weeks before starting the study.

\section{Fieldwork:}

Data were collected within one semester of the academic year 2016; the study was conducted by the researcher for the studied sample in the selected settings at Faculty of Nursing students, El Fayoum University, two days per week for interviewing the Faculty of Nursing students.

Program Development Included 3 Phases:

\section{Phase (I):- program preparation:}

Based on the results obtained from the interviewing, as well as literature review, the health educational program was developed by the researcher. It was implemented immediately after the pre-test.

General objective: Apply health educational program to improve the nursing students' knowledge and practice regarding healthy use of mobile phone.

Contents of program: Content of the program was designed to meet university students' needs and to fit into their interest and levels of understanding. The health educational content include the following : mobile phone definition, uses of mobile phone, types of electromagnetic field, the physical, social, and economical health and academic effects of mobile phone on nursing students, practices related healthy use of mobile phone.

Teaching Methods: All university students received the same program content using the same teaching methods, there were: Lectures/Discussions, demonstration and re-demonstrations and role play.

Teaching aids: Suitable teaching aids were specially prepared for the program, as follows: Flip charts, pictures and hand out.

\section{Phase (II): Implementation of the program:}

The researchers utilized multiple sessions ranged from 8-10 sessions (theory and practice), and each session needed from 1-2 hours including periods of discussion pretest and posttest, and meeting with students was two days per week. Students were present, all the time of the program sessions. The duration of each session was variable, according to its contents as well as the students' response.

The students were divided into groups. The program was implemented for students at the suitable time for them. To insure that they were exposed to the same learning experience, they received the same program content and used to same teaching strategies. 
At the beginning of the first session, an orientation to the program and its process were presented. Each session started by a summary about what had been given through the previous session then the objectives of the new topics, taking into consideration the use of simple language to suite the level of students. Discussion, motivation and reinforcement during program sessions were used to enhance learning. Direct reinforcement in the form of a copy of the program was given as a gift for each student to use it as future reference. All the participants were cooperative with the researcher. At the end of each session, students participated in a discussion to correct any misunderstanding, and informed about the time of the next session.

\section{Phase (III): Evaluation of the program:}

Evaluation of the program was done by using the posttest questionnaire which was the same format of pre-test in order to evaluate the effect of health educational program to Faculty of Nursing students about healthy use of mobile phone, immediately after implementation of the program.

\section{Administrative Design:}

An official permission to conduct the study was obtained from the Dean of the Faculty of Nursing, El Fayoum University for applying the study in the Faculty of Nursing. The title, objectives, study technique and tools were illustrated for cooperation, as well as to allow the researcher to prepare a regular arrangement with students.

\section{Ethical considerations:}

Permission was obtained from each student before conducting the interview and after giving them a brief orientation to the purpose of the study, they were assured that their participation in the study is voluntary. They were also reassured that the information gathered would be confidential and used for the purpose of the study. No names were required on the forms to ensure anonymity and confidentiality. They were also informed about their right to withdraw at any time from the study without giving any reasons.

\section{Statistical Analysis:}

Data collected were analyzed using the Statistical Package for Social Sciences (SPSS), version 20. Data were presented using descriptive statistics in the form of frequencies and percentages. Chi-square test $\left(\mathrm{X}^{2}\right)$ was used for comparisons between qualitative variables. Statistical significance was considered at p-value $<0.05$.

\section{Results}

Table (1) explains the difference in students' knowledge about healthy use of mobile phone pre and post program. there were statistically significant differences between the studied subjects' knowledge about meaning of cell phone, function of cell phone, type of cell phone radiation, the distance between the cell phone and the eye, changes of cell phone on the body, effects of radiation from cell phone, effects of electromagnetic waves, effects of sleeping near to a cell phone, effects of long term use throughout the program $(\mathrm{p}<0.05)$. In relation to studied subjects' knowledge about uses of cell phone and effects of waves on visual and auditory organ, there were statistically insignificant differences between the studied subjects' knowledge about uses of cell phone and effects of waves on visual and auditory throughout the program $(\mathrm{p}>0.05)$.

Table (2): Shows that there were statistically significant differences between studied subjects practices regarding aspects as receiving calls, during communication, carrying a cell phone and using multimedia throughout the program $(\mathrm{p}<0.05)$

Table (3): Reveals that, $52.0 \%$ of the studied sample was male, $39.6 \%$ of them were in the age group $21-<23$ years with a mean age $23.15 \pm 2.11$, and $20.3 \%$ of them were in third grade of faculty. In relation to ranking, the table shows that, $30.5 \%$ were ranked as the first and $50.8 \%$ of them reside rural areas.

Table (4): Shows that $73.4 \%$ of students were using mobile phone to read notes and $73.4 \%$ of them were using mobile phone to check/post on social networking sites.

Table (5): Shows that $68.4 \%$ of students had one cell phone, $84.7 \%$ of them their duration of use a cell phone ranged between 5-10 years, for 53.6\% their average time per call ranged between 6-10 minutes, $68.4 \%$ their average time per day was less than an hour and $52.5 \%$ did not live near the cell phone booster station networks. 
Figure (1): Shows that $37.0 \%$ of them received information about cell phone from media Table (6): Clarifies that, there were statistically insignificant differences between impact of cell phone on physical aspect of the studied subjects throughout the program $(\mathrm{p}>0.05)$.

Table (7): Shows that there was statistically insignificant difference between impact of cell phone on social aspect of the studied subjects throughout the program $(\mathrm{p}>0.05)$.

Table (8): Shows that there were statistically insignificant differences between impact of cell phone on economic aspect of the studied subjects throughout the program $(p>0.05)$

Table (9): Clarifies that there were statistically significant relations between gender, grades and residence of the studied subjects and their knowledge regarding cell phone throughout the program $(\mathrm{p}<0.05)$. However, there were statistically insignificant differences between age, and ranking of the studied subjects and their knowledge regarding cell phone throughout the program $(\mathrm{p}>0.05)$.

Table (10): Reveals that there were statistically significant relations between gender, age, rank and residence of the studied subjects and their practices as stated by them regarding cell phone throughout the program $(p<0.05)$. However, there was a statistically insignificant difference between grade of the studied subjects and their practices regarding cell phone throughout the program $(\mathrm{p}>0.05)$.

Table (11): Clarifies that, there were statistically insignificant differences between characteristics of the studied subjects and impact of cell phone on their physical, social and economic aspects throughout the program $(\mathrm{p}>0.05)$.

\section{Discussion}

Cell phones are a pensive new communication technology, especially among university students. Since are possible risks will occur related to prolonged unhealthy use of mobile. As regards studied subjects characteristics, the current study finding revealed that, more than half of them were male, while more than one third of them were in the age group $21-<23$ years with a mean \pm SD of $23.15 \pm 2.11$, and also, one third of them were in the fourth grade of faculty. In relation to rank among family members, the result revealed that nearly one third of them were ranked as the first in addition to slightly more than half of them were living in rural areas (table 3). These results were supported by those of the study of Kanwal and Archana (2014), on "Internet addiction in students: A cause of concern" and mentioned that the Internet was originally designed to facilitate communication and research activities. This study carried out in India is a preliminary investigation of the extent of Internet students aged 16-21 years. They found that their mean \pm SD age also was 21.15 \pm 2.11 , and most of them were in the second to third grade.

In relation to the studied subjects and their cell phone academic and non-academic activities the current study finding revealed that nearly three quarter of them were using mobile phones to read notes and to check/post on social networking site (table 4). This study was supported by of Bassett-Gunter and Chang (2016), who recently studied self-regulatory self-efficacy, action control, and planning: Telemedicine and ehealth and mentioned that using phone to check/post on social networking site was vitally spread recently and every one used it to facilitate the academic activities.

Concerning the number of cell phones used by the studied students, the current study finding showed that more than two third of them had one cell phone, and the majority of them started to use a cell phone since 5-10 years, in addition more than half of them their average time per call ranged between 6-10 minutes, while more than two third of them, their average time was less than an hour a day and meanwhile more than half of them do not live near the cell phone booster station networks (table 5). These study findings were supported by those of the very recent study of Jiang and Beaudoin (2016), whose entitled "Smoking prevention in china: A content analysis of an anti-smoking social media campaign", mentioned that most of the study sample are having their phones 10 years ago and were using them many times per day. Also, North et al. (2014) stated that the average length of calls varied amongst the respondents. The most frequent average call length was 1-2 minutes (27\%), closely followed by 2-4 minutes (25\%), 0.5-1 minute (18\%), 4-8 minutes (13\%), 9+ minutes (12\%) and 0-30 seconds $(6 \%)$ The investigators believe that this may be due to the invasive of such technology among Egyptians' life, which enabled the studied sample to do their communication and their activities through using cell phone. 
As for the source of information about cell phone, the current study finding illustrated that more than half of them received information about cell phone from media. This study result was supported by that of Santosh et al. (2009), who mentioned that most of the study sample received information about cell phone from media such as internet and the majority of them were going to the cell centers to know any new applications about the last updated once.

The current study findings clarified that, there were statistically significant differences between the studied subjects' knowledge pre/post program about meaning of cell phone, function of cell phone, type of cell phone radiation, distance between the cell phone and the eye, changes of cell phone on the body, effects of radiation from cell phone, effects of electromagnetic waves, effects of sleeping next to a cell phone and effects of long term use throughout the program $(\mathrm{p}<0.05)$. These findings were in agreement with a study which revealed that there was a very significant difference shown in the knowledge and perception of mobile health and its effectiveness at $\mathrm{P} 1(\mathrm{p}=0.012$ and 0.017$)$ but this significance faded away 6 months after $(\mathrm{p}=0.312$ and 0.598$)$ respectively(Titilayo \& Okanlawon, 2014).

In relation to the studied subjects knowledge about use of cell phone and effects of waves on visual and auditory organ, there was a statistically insignificant difference between the studied subjects' knowledge about use of cell phone and effects of waves on auditory organ throughout the program ( $>>0.05)$ (table 1). This study result was supported by Elgerjawy et al. (2015), who studied "The effect of information technology based intervention on glycemic control of children suffering from diabetes in Gaza Strip", and revealed that the knowledge of the studied sample about the meaning and the methods of information technology, namely cell phone was satisfactory before the intervention, because the majority of them have previous knowledge and experience about information technology from school classes or university according to the system of Palestinian curriculum. In addition, there is availability for the facilities of IT methods as internet, mobile phone, computer, memory flash, E-mail, SMS, and CD. This could be clear in the present study, as the great majority of the studied sample had a satisfactory knowledge pre the IT based intervention. This result could be due to the curiosity of the studied sample at this age period to use IT.

The current study result clarified that there were statistically significant differences between the studied subjects practices pre/post program as stated by them regarding receiving calls, during communicating, carrying a cell phone and using multimedia throughout the program $(\mathrm{p}<0.05)$. However, there were statistically insignificant differences between impact of cell phone on social aspects of the studied subjects throughout the program ( $>0.05$ ) (table 2). These study findings were in accordance with Al-Shafi (2008), who studying the relation between IT, knowledge and practices; found that, there were positive correlations between information technology, knowledge and practices among the studied sample.

The current finding indicated that there were statistically insignificant differences between effect of cell phone on physical, social and economic aspects of the studied subject throughout the program ( $\mathrm{p}>0.05)($ table 6,7\&8). This study finding was highly supported by the study of Wilkinson et al. (2008), who carried out a feasibility study of home telemedicine and found similar findings as regards to the mean value of psychological economic aspects pre and post IT based intervention; and a statistically significant difference was observed. However this finding contradicted with McManis and Gunnewing (2012), who's found the education in technology with early learners revealed that cell phone affects on cultural and economic aspects.

The current study finding clarified that there were statistically significant relations between gender, grades and residence of the studied subjects and their knowledge regarding cell phone throughout the program $(\mathrm{p}<0.05)$, while there were statistically insignificant differences between age, and rank of the studied subjects and their knowledge regarding cell phone throughout the program ( $>>0.05$ ) ( table 9). The Institute of Medicine (2011) reported in "The Committee on Quality of Health Care in America. Crossing the Quality Chasm", that there were statistically insignificant differences between age, and ranking of the studied subjects and their knowledge regarding cell phone. The investigators believe that the age did not affect on the knowledge of the cell phone because regarding the huge fast invasion of technology in homes can make the children and youth know more about cell phone than their parents or teachers.

In the present study, there were statistically significant differences between some characteristics as; gender, age, ranking and residence of the studied subjects and their practices regarding cell phone use throughout the program $(\mathrm{p}<0.05)$, while there was a statistically insignificant difference between the study grades of the studied subjects and their practices regarding cell phone use throughout the program $(\mathrm{p}>0.05)$. In addition, there were statistically insignificant differences between characteristics of the studied subjects and effect of cell phone on their physical, social, and economic aspects throughout the program ( $p>0.05)$ (table 10, 11). In a similar study, 
Chih-pin (2009), who studied the relation between information technology and the child's level of education, they observed that a positive relation between information technology and the level of education of the studied subjects especially among university students. The author also found that there was statistically insignificant difference between characteristics of the studied subjects and effect of cell phone use on their physical, social and economic aspects throughout the program.

\section{Conclusion}

According to the study findings and research questions, it is concluded that, there were significant improvements in the student's knowledge regarding healthy mobile phone use, healthy practices of mobile phone as they sated at the post test when compared with pretest. However, there was insignificant improvement in physical, social and economic effects of mobile phone on Faculty of Nursing students at the post test same of pretest.

\section{Recommendations}

Based on the findings of the current study, the following recommendations are suggested:

- Developing a health educational program for students about biopsychosocial effects of mobile phone.

- More studies in this field are urgently needed with large probability sample from different geographical areas to allow greater representation and generalization of the results

- Further researches to be carried out about phone healthy use and practices based on educational needs to improve faculty of nursing students' knowledge and practices regarding healthy mobile phone personal use.

Table (1): Number and percentage distribution of the studied subjects according to their correct knowledge $(\mathrm{n}=177)$

\begin{tabular}{|c|c|c|c|c|c|c|}
\hline \multirow[t]{2}{*}{ Correct Knowledge } & \multicolumn{2}{|c|}{ Pre program } & \multicolumn{2}{|c|}{ Post program } & \multirow{2}{*}{$X^{2}$} & \multirow{2}{*}{$\begin{array}{c}\mathrm{P} \\
\text { Value }\end{array}$} \\
\hline & No & $\%$ & No & $\%$ & & \\
\hline Function of cell phone & 34 & 19.2 & 49 & 27.7 & 12.67 & 0.01 \\
\hline Uses of cell phone & 94 & 53.1 & 100 & 56.5 & 0.95 & 0.81 \\
\hline Type of cell phone radiation & 27 & 15.2 & 38 & 21.5 & 15.23 & 0.002 \\
\hline Distance between the cell phone and the eye & 52 & 29.4 & 88 & 49.7 & 16.17 & 0.001 \\
\hline Changes of cell phone on the body & 41 & 23.2 & 67 & 37.8 & 9.65 & 0.01 \\
\hline Effects of radiation from cell phone & 38 & 21.5 & 48 & 27.1 & 18.32 & 0.001 \\
\hline Effects of electromagnetic waves & 6 & 3.4 & 19 & 10.7 & 10.15 & 0.02 \\
\hline Effects of waves on visual and auditory organ & 92 & 52.0 & 99 & 56.0 & 1.54 & 0.67 \\
\hline Effects of sleeping next to a cell phone & 22 & 12.4 & 43 & 24.3 & 10.06 & $\mathbf{0 . 0 2}$ \\
\hline Effects of long term use & 30 & 17.0 & 59 & 33.3 & 13.94 & 0.01 \\
\hline Total & 41 & 23.2 & 60 & 33.9 & 5.438 & 0.02 \\
\hline
\end{tabular}

Table (2): Distribution of the studied subjects according to their practices as stated by them regarding use of cell phone phones $(\mathrm{n}=177)$

\begin{tabular}{|c|c|c|c|c|c|c|c|c|}
\hline \multirow{3}{*}{ Practices } & \multicolumn{3}{|c|}{ Pre program } & \multicolumn{3}{|c|}{ Post program } & \multirow{3}{*}{$X^{2}$} & \multirow{3}{*}{$\begin{array}{c}\mathrm{P} \\
\text { Value }\end{array}$} \\
\hline & Always & Sometimes & Never & Always & Sometimes & Never & & \\
\hline & $\%$ & $\%$ & $\%$ & $\%$ & $\%$ & $\%$ & & \\
\hline Receiving calls & 19.8 & 23.7 & 56.5 & 31.1 & 25.4 & 43.5 & 7.5 & 0.02 \\
\hline During communication & 61.6 & 17.5 & 20.9 & 50.7 & 28.4 & 20.9 & 6.2 & 0.04 \\
\hline Carrying a cell phone & 53.7 & 26.0 & 20.3 & 44.1 & 22.0 & 33.9 & 8.2 & 0.02 \\
\hline Using multimedia & 46.3 & 3.1 & 22.6 & 40.1 & 24.9 & 35.0 & 6.7 & $\mathbf{0 . 0 3}$ \\
\hline Total & 45.7 & 24.3 & 30.0 & 33.3 & 25.4 & 41.3 & 6.7 & 0.03 \\
\hline
\end{tabular}

Table (3): Number and percentage distribution of the studied subjects according to their personal and educational characteristics $(n=177)$

\begin{tabular}{|c|c|c|}
\hline Items & No & $\%$ \\
\hline \multicolumn{3}{|l|}{ Gender } \\
\hline Male & 92 & 52.0 \\
\hline Female & 85 & 48.0 \\
\hline
\end{tabular}


Effect of an Educational Program on Healthy Use of Mobile Phone among Faculty of Nursing ..

\begin{tabular}{|c|c|c|}
\hline$<18$ & 45 & 25.4 \\
\hline 19- & 40 & 22.6 \\
\hline $21-$ & 70 & 39.6 \\
\hline $23+$ & 22 & 12.4 \\
\hline Mean \pm SD & \multicolumn{2}{|c|}{$23.15 \pm 2.11$} \\
\hline \multicolumn{3}{|l|}{ Grade } \\
\hline First & 30 & 17.0 \\
\hline Second & 52 & 29.4 \\
\hline Third & 36 & 20.3 \\
\hline Fourth & 59 & 33.3 \\
\hline \multicolumn{3}{|l|}{ Rank } \\
\hline First & 54 & 30.5 \\
\hline Second & 47 & 26.6 \\
\hline Third & 42 & 23.7 \\
\hline Fourth & 34 & 19.2 \\
\hline \multicolumn{3}{|l|}{ Residence } \\
\hline Urban & 87 & 49.2 \\
\hline Rural & 90 & 50.8 \\
\hline
\end{tabular}

Table (4): Number and percentage distribution of the studied subjects according to their cell phone academic \& non-academic activities $(\mathrm{n}=177)$

\begin{tabular}{|c|c|c|}
\hline Items & No & $\%$ \\
\hline \multicolumn{3}{|l|}{ Academic Activities } \\
\hline Access work-related to study references & 10 & 5.6 \\
\hline Access sites related to nursing & 35 & 19.8 \\
\hline Read lecture notes & 45 & 25.4 \\
\hline Looking international \& national nursing studies & 52 & 29.4 \\
\hline Submit assessment tasks & 81 & 45.8 \\
\hline Access study (library, journal, articles) & 92 & 52.0 \\
\hline Browse (e.g., use a search engine Google) & 110 & 62.1 \\
\hline Share notes & 130 & 73.4 \\
\hline \multicolumn{3}{|l|}{ Non Academic Activities } \\
\hline Shop on the Internet & 11 & 6.2 \\
\hline Play online games & 42 & 23.7 \\
\hline Check/post on social networking sites & 130 & 73.4 \\
\hline Use personal emails to family / friends & 162 & 69.0 \\
\hline
\end{tabular}

Table (5): $\quad$ Number and percentage distribution of the studied subjects according to their cell phone \& its uses $(\mathrm{n}=177)$

\begin{tabular}{|c|c|c|}
\hline$\overline{\text { Items }}$ & No & $\%$ \\
\hline \multicolumn{3}{|l|}{ Number of cell phone } \\
\hline One & 121 & 68.4 \\
\hline Two & 29 & 16.4 \\
\hline Three & 27 & 15.2 \\
\hline \multicolumn{3}{|l|}{ Type of cell phone } \\
\hline Normal & 35 & 19.8 \\
\hline Multimedia & 142 & 80.0 \\
\hline \multicolumn{3}{|l|}{ Duration of use a cell phone (in years) } \\
\hline $1-<5$ & 5 & 2.9 \\
\hline $5-10$ & 150 & 84.7 \\
\hline More than 10 & 22 & 12.4 \\
\hline \multicolumn{3}{|l|}{ Average time per call (in minutes) } \\
\hline$<3$ & 37 & 21.0 \\
\hline $3-6$ & 45 & 25.4 \\
\hline $6-10$ & 95 & 53.6 \\
\hline \multicolumn{3}{|l|}{ Average time per day } \\
\hline$<$ an hour a day & 121 & 68.4 \\
\hline 1-2 hours a day & 47 & 26.5 \\
\hline 3-5 hours a day & 9 & 5.1 \\
\hline \multicolumn{3}{|l|}{ Live near the cell phone booster station networks } \\
\hline Yes & 37 & 21.0 \\
\hline No & 93 & 52.5 \\
\hline I don't know & 47 & 26.5 \\
\hline
\end{tabular}


Figure 1: Percentage distribution of the studied subjects according to their information about cell phone

$(\mathrm{n}=177)$

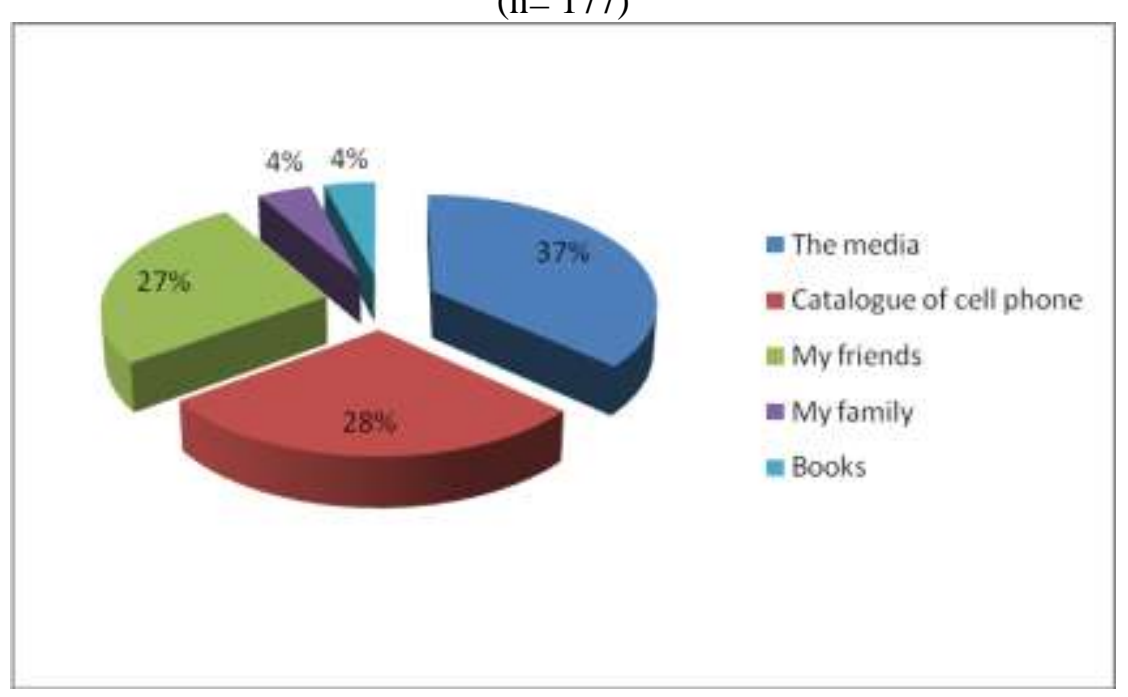

Table (6): Distribution of the studied subjects according to cell phone effects on their physical aspect $(\mathrm{n}=177)$.

\begin{tabular}{|c|c|c|c|c|c|c|c|c|}
\hline \multirow{3}{*}{ Effects } & \multicolumn{3}{|c|}{ Pre program } & \multicolumn{3}{|c|}{ Post program } & \multirow{3}{*}{$X^{2}$} & \multirow{3}{*}{$\begin{array}{c}\mathrm{P}- \\
\text { value }\end{array}$} \\
\hline & Always & Sometimes & Never & Always & Sometimes & Never & & \\
\hline & $\%$ & $\%$ & $\%$ & $\%$ & $\%$ & $\%$ & & \\
\hline Headache when used for long periods & 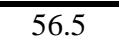 & 22.6 & 21.0 & 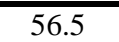 & 22.6 & 21.0 & 0.0 & 1.0 \\
\hline Pain in the ear when used for long periods & 45.2 & 28.2 & 26.6 & 45.2 & 28.2 & 26.6 & 0.0 & 1.0 \\
\hline Pain in the eye when used for long periods & 33.9 & 33.9 & 32.2 & 33.9 & 33.9 & 32.2 & 0.0 & 1.0 \\
\hline $\begin{array}{l}\text { Pain in the back, shoulder and neck when } \\
\text { used for long periods }\end{array}$ & 31.1 & 25.4 & 43.5 & 31.1 & 25.4 & 43.5 & 0.0 & 1.0 \\
\hline $\begin{array}{l}\text { Rise in body temperature when used for } \\
\text { long periods }\end{array}$ & 40.7 & 22.6 & 36.7 & 40.7 & 22.6 & 36.7 & 0.0 & 1.0 \\
\hline $\begin{array}{l}\text { tachycardia (increased heart rate) when } \\
\text { used for long periods }\end{array}$ & 32.8 & 25.4 & 41.8 & 32.8 & 25.4 & 41.8 & 0.0 & 1.0 \\
\hline $\begin{array}{l}\text { Sluggish and public fatigue when used for } \\
\text { long periods }\end{array}$ & 38.4 & 45.2 & 16.4 & 38.4 & 45.2 & 16.4 & 0.0 & 1.0 \\
\hline Sense of tension and nervousness & 47.5 & 38.4 & 14.1 & 47.5 & 38.4 & 14.1 & 0.0 & 1.0 \\
\hline $\begin{array}{l}\text { Insomnia and inability to sleep when } \\
\text { putting it next to you during sleep }\end{array}$ & 45.2 & 37.9 & 16.9 & 45.2 & 37.9 & 16.9 & 0.0 & 1.0 \\
\hline $\begin{array}{l}\text { Poor memory and lack of concentration } \\
\text { and absorption }\end{array}$ & 50.7 & 28.4 & 20.9 & 50.7 & 28.4 & 20.9 & 0.0 & 1.0 \\
\hline
\end{tabular}


Table (7): Distribution of the studied subjects according to cell phone effects on their social aspect $(\mathrm{n}=177)$.

\begin{tabular}{|c|c|c|c|c|c|c|c|c|}
\hline \multirow{3}{*}{ Effects } & \multicolumn{3}{|c|}{ Pre program } & \multicolumn{3}{|c|}{ Post program } & \multirow{3}{*}{$X^{2}$} & \multirow{3}{*}{$\begin{array}{c}\mathrm{P} \\
\text { Value }\end{array}$} \\
\hline & Always & Sometimes & Never & Always & Sometimes & Never & & \\
\hline & $\%$ & $\%$ & $\%$ & $\%$ & $\%$ & $\%$ & & \\
\hline Excessive use wasting time & 22.6 & 18.1 & 59.3 & 22.6 & 18.1 & 59.3 & 0.0 & 1.0 \\
\hline $\begin{array}{l}\text { Feel happy when you connect with } \\
\text { others }\end{array}$ & 45.2 & 28.2 & 26.6 & 45.2 & 28.2 & 26.6 & 0.0 & 1.0 \\
\hline $\begin{array}{l}\text { Lose control of myself when I forget } \\
\text { at home or lose }\end{array}$ & 33.9 & 33.9 & 32.2 & 33.9 & 33.9 & 32.2 & 0.0 & 1.0 \\
\hline $\begin{array}{l}\text { Affect the use of dedicated study } \\
\text { time }\end{array}$ & 40.7 & 22.6 & 36.7 & 40.7 & 22.6 & 36.7 & 0.0 & 1.0 \\
\hline $\begin{array}{l}\text { Adversely affect the behavior of } \\
\text { university student }\end{array}$ & 38.4 & 45.2 & 16.4 & 38.4 & 45.2 & 16.4 & 0.0 & 1.0 \\
\hline $\begin{array}{l}\text { Lead to feelings of isolation and social } \\
\text { alienation and cultural aspect }\end{array}$ & 19.8 & 23.7 & 56.5 & 19.8 & 23.7 & 56.5 & 0.0 & 1.0 \\
\hline Illegal acquaintance between the sexes & 31.1 & 25.4 & 43.5 & 31.1 & 25.4 & 43.5 & 0.0 & 1.0 \\
\hline $\begin{array}{l}\text { Environment for the spread of } \\
\text { rumors and scandals }\end{array}$ & 55.4 & 30.5 & 14.1 & 55.4 & 30.5 & 14.1 & 0.0 & 1.0 \\
\hline Considered as a means of liberation & 54.2 & 24.3 & 21.5 & 54.2 & 24.3 & 21.5 & 0.0 & 1.0 \\
\hline $\begin{array}{l}\text { Seen as a way to empty the internal } \\
\text { repression }\end{array}$ & 46.9 & 37.8 & 15.3 & 46.9 & 37.8 & 15.3 & 0.0 & 1.0 \\
\hline
\end{tabular}

Table (8): Percentage distribution of the studied subjects according to cell phone effect on their economic aspect $(n=177)$

\begin{tabular}{|c|c|c|c|c|c|c|c|c|}
\hline \multirow{3}{*}{ Item } & \multicolumn{3}{|c|}{ Pre program } & \multicolumn{3}{|c|}{ Post program } & \multirow{3}{*}{$\mathrm{X}^{2}$} & \multirow{3}{*}{$\begin{array}{c}\mathrm{P}- \\
\text { value }\end{array}$} \\
\hline & Always & Sometimes & Never & Always & Sometimes & Never & & \\
\hline & $\%$ & $\%$ & $\%$ & $\%$ & $\%$ & $\%$ & & \\
\hline Wasting money & 52.6 & 27.1 & 20.3 & 52.6 & 27.1 & 20.3 & 0.0 & 1.0 \\
\hline $\begin{array}{l}\text { Requires significant } \\
\text { maintenance }\end{array}$ & 53.7 & 26.0 & 20.3 & 53.7 & 26.0 & 20.3 & 0.0 & 1.0 \\
\hline $\begin{array}{l}\text { Spends a large part of the money on } \\
\text { updated each period }\end{array}$ & 45.7 & 37.3 & 17.0 & 45.7 & 37.3 & 17.0 & 0.0 & 1.0 \\
\hline
\end{tabular}

Table (9): Relation between characteristics of the studied subject and their knowledge regarding cell phone throughout the program

\begin{tabular}{|c|c|c|c|c|c|c|c|}
\hline \multirow{3}{*}{ Characteristics } & \multirow{3}{*}{ Correct Answers } & \multicolumn{2}{|c|}{ Pre program } & \multicolumn{2}{|c|}{ Post program } & \multirow{3}{*}{$X^{2}$} & \multirow{3}{*}{$\begin{array}{c}\mathrm{P}- \\
\text { value }\end{array}$} \\
\hline & & Known & Unknown & Known & Unknown & & \\
\hline & & $\%$ & $\%$ & $\%$ & $\%$ & & \\
\hline \multicolumn{6}{|l|}{ Gender } & \multirow{3}{*}{8.85} & \multirow{3}{*}{0.03} \\
\hline Male & & 11.9 & 40.1 & 22.6 & 29.4 & & \\
\hline Female & & 11.3 & 36.7 & 11.3 & 36.7 & & \\
\hline \multicolumn{6}{|l|}{ Age } & \multirow{5}{*}{5.97} & \multirow{5}{*}{0.5} \\
\hline$<18$ & & 6.8 & 18.6 & 11.3 & 14.1 & & \\
\hline $18-<19$ & & 6.2 & 16.4 & 8.5 & 14.1 & & \\
\hline $19-<21$ & & 5.1 & 34.5 & 6.8 & 32.8 & & \\
\hline$<23$ & & 5.1 & 7.3 & 7.3 & 5.1 & & \\
\hline \multicolumn{6}{|l|}{ Grades } & \multirow{5}{*}{7.02} & \multirow{5}{*}{0.04} \\
\hline First & & 5.6 & 16.9 & 6.8 & 15.8 & & \\
\hline Second & & 5.1 & 11.9 & 7.9 & 9.0 & & \\
\hline Third & & 8.5 & 25.4 & 11.3 & 22.6 & & \\
\hline Fourth & & 3.9 & 22.6 & 7.9 & 18.6 & & \\
\hline
\end{tabular}


Effect of an Educational Program on Healthy Use of Mobile Phone among Faculty of Nursing ..

\begin{tabular}{|c|c|c|c|c|c|c|}
\hline \multicolumn{5}{|l|}{ Rank } & \multirow{5}{*}{5.49} & \multirow{5}{*}{0.5} \\
\hline First & 7.9 & 22.6 & 13.0 & 17.5 & & \\
\hline Second & 7.3 & 19.2 & 9.6 & 16.9 & & \\
\hline Third & 4.5 & 19.2 & 6.2 & 17.5 & & \\
\hline Fourth & 3.4 & 15.2 & 5.1 & 14.1 & & \\
\hline Residence & & & & & \multirow{3}{*}{7.95} & \multirow{3}{*}{0.04} \\
\hline Urban & 10.1 & 39.0 & 19.8 & 29.4 & & \\
\hline Rural & 13.0 & 37.9 & 14.1 & 36.7 & & \\
\hline
\end{tabular}


Effect of an Educational Program on Healthy Use of Mobile Phone among Faculty of Nursing ..

Table (10): Relations between characteristics of the studied subjects and their practices as stated by them regarding cell phone throughout the program

\begin{tabular}{|c|c|c|c|c|c|c|c|c|c|}
\hline \multirow{3}{*}{ Characteristics } & \multirow{3}{*}{ Practices } & \multicolumn{3}{|c|}{ Pre program } & \multicolumn{3}{|c|}{ Post program } & \multirow{2}{*}{$X^{2}$} & \multirow{2}{*}{$\begin{array}{c}\mathrm{P} \\
\text { Value }\end{array}$} \\
\hline & & Always & Sometimes & Never & Always & Sometimes & Never & & \\
\hline & & $\overline{\%}$ & $\overline{\%}$ & $\overline{\%}$ & $\overline{\%}$ & $\overline{\%}$ & $\overline{\%}$ & \multirow{4}{*}{11.72} & \multirow{4}{*}{0.03} \\
\hline \multicolumn{8}{|l|}{ Gender } & & \\
\hline Male & & 29.4 & 11.9 & 10.7 & 22.6 & 8.5 & 20.9 & & \\
\hline Female & & 16.4 & 12.4 & 19.2 & 10.7 & 17.0 & 20.3 & & \\
\hline Age & & & & & & & & \multirow{5}{*}{8.28} & \multirow{5}{*}{0.04} \\
\hline$\leq 18$ & & 8.5 & 11.3 & 5.6 & 6.8 & 9.6 & 9.0 & & \\
\hline 19- & & 9.6 & 8.5 & 4.5 & 8.5 & 7.3 & 6.8 & & \\
\hline $21-$ & & 22.6 & 2.8 & 14.1 & 16.4 & 6.8 & 16.4 & & \\
\hline$>23$ & & 5.1 & 1.7 & 5.6 & 1.7 & 1.7 & 9.0 & & \\
\hline \multicolumn{8}{|l|}{ Grade } & \multirow{5}{*}{7.12} & \multirow{5}{*}{0.05} \\
\hline First & & 5.6 & 6.2 & 5.1 & 4.5 & 8.5 & 9.6 & & \\
\hline Second & & 11.3 & 5.6 & 5.6 & 5.6 & 5.1 & 6.2 & & \\
\hline Third & & 22.6 & 7.3 & 4.0 & 17.5 & 6.8 & 9.6 & & \\
\hline Fourth & & 6.2 & 5.1 & 15.2 & 5.6 & 5.1 & 15.8 & & \\
\hline \multicolumn{8}{|l|}{ Rank } & \multirow{5}{*}{9.6} & \multirow{5}{*}{0.03} \\
\hline First & & 12.4 & 11.3 & 6.8 & 8.5 & 10.1 & 11.9 & & \\
\hline Second & & 13.0 & 5.6 & 8.9 & 8.5 & 5.6 & 12.4 & & \\
\hline Third & & 9.6 & 4.5 & 9.6 & 10.1 & 6.8 & 6.8 & & \\
\hline Fourth & & 10.7 & 2.8 & 5.6 & 6.2 & 2.8 & 10.1 & & \\
\hline \multicolumn{8}{|l|}{ Residence } & \multirow{3}{*}{24.41} & \multirow{3}{*}{0.0002} \\
\hline Urban & & 17.5 & 14.7 & 17.0 & 8.5 & 5.6 & 18.1 & & \\
\hline Rural & & 28.2 & 9.6 & 13.0 & 24.8 & 19.8 & 23.8 & & \\
\hline
\end{tabular}

Table (11): Relations between characteristics of the studied subjects and cell phone effect on their physical, social and economic aspects throughout the program

\begin{tabular}{|c|c|c|c|c|c|c|c|c|}
\hline \multirow{3}{*}{ Practices } & \multicolumn{3}{|c|}{ Pre program } & \multicolumn{3}{|c|}{ Post program } & \multirow{3}{*}{$X^{2}$} & \multirow{3}{*}{$\begin{array}{c}\mathrm{P} \\
\text { Value }\end{array}$} \\
\hline & Always & Sometimes & Never & Always & Sometimes & Never & & \\
\hline & $\%$ & $\%$ & $\%$ & $\%$ & $\%$ & $\%$ & & \\
\hline \multicolumn{7}{|l|}{ Gender } & \multirow{3}{*}{0.0} & \multirow{3}{*}{1.0} \\
\hline Male & 27.1 & 14.1 & 10.7 & 27.1 & 14.1 & 10.7 & & \\
\hline Female & 22.6 & 18.6 & 6.8 & 22.6 & 18.6 & 6.8 & & \\
\hline \multicolumn{7}{|l|}{ Age } & \multirow{5}{*}{0.0} & \multirow{5}{*}{1.0} \\
\hline$\geq 18$ & 11.9 & 10.2 & 3.4 & 11.9 & 10.2 & 3.4 & & \\
\hline $19-$ & 12.4 & 5.1 & 5.1 & 12.4 & 5.1 & 5.1 & & \\
\hline $21-$ & 19.8 & 11.3 & 8.5 & 19.8 & 11.3 & 8.5 & & \\
\hline$>23$ & 5.6 & 6.2 & 0.6 & 5.6 & 6.2 & 0.6 & & \\
\hline \multicolumn{7}{|l|}{ Grades } & \multirow{5}{*}{0.0} & \multirow{5}{*}{1.0} \\
\hline First & 11.3 & 7.3 & 4.0 & 11.3 & 7.3 & 4.0 & & \\
\hline Second & 5.1 & 6.8 & 5.1 & 5.1 & 6.8 & 5.1 & & \\
\hline Third & 13.6 & 13.6 & 6.8 & 13.6 & 13.6 & 6.8 & & \\
\hline Fourth & 19.8 & 5.1 & 1.7 & 19.8 & 5.1 & 1.7 & & \\
\hline \multicolumn{7}{|l|}{ Rank } & \multirow{5}{*}{0.0} & \multirow{5}{*}{1.0} \\
\hline First & 16.4 & 9.6 & 4.5 & 29 & 17 & 8 & & \\
\hline Second & 12.4 & 8.5 & 5.6 & 22 & 15 & 10 & & \\
\hline Third & 10.2 & 9.6 & 4.0 & 18 & 17 & 7 & & \\
\hline Fourth & 10.7 & 5.1 & 3.4 & 19 & 9 & 6 & & \\
\hline \multicolumn{7}{|l|}{ Residence } & \multirow{3}{*}{0.0} & \multirow{3}{*}{1.0} \\
\hline Urban & 26.0 & 15.8 & 7.3 & 26.0 & 15.8 & 7.3 & & \\
\hline Rural & 23.7 & 17.0 & 10.2 & 23.7 & 17.0 & 10.2 & & \\
\hline
\end{tabular}

\section{References}

[1]. Al-Shafi, S. (2008): Free Wireless Internet park Services: An Investigation of Technology Adoption in Qatar from a Citizens' Perspective," Journal of Cases on Information Technology, 10:21-34.

[2]. Ames M.G. (2013): Managing mobile multitasking: the culture of iPhones on stanford campus," in Proceedings of the 2013 conference on Computer supported cooperative work, pp. 1487-1498.

[3]. Arif, I., \& Aslam, W. (2014): Students' dependence on smart phone and its effect on purchase behaviour. Munich Personal RePEc Archive; 58919:1-11. 
[4]. Bassett-Gunter, R. \& Chang, A. (2016): Self-regulatory self-efficacy, action control, and planning: There's an app for that!. Telemedicine and e-Health; 22(4):325.

[5]. Beniwal, M.K., \& Sharma, A. (2013): "Explosive growth of mobile technology and its potential impact on youth \& education," International Journal of Application or Innovation in Engineering \& Management (IJAIEM) Web Site: www.ijaiem.org Email: editor@ijaiem.org, editorijaiem@gmail.com Volume 2, Issue 4, April 2013.

[6]. Bhise, A.T., Ghatule, A.A., \& Ghatule, A.P. (2014): Study of mobile addiction among students W.R.T. Gender and education. Indian Journal of Research in Management, Business and Social Sciences.; 2(1):17-21.

[7]. Chih-pin, L. (2009): The study of web-based teaching material in nature field on primary students' learning achievement and attitude-an example of beautiful star. Sociology of National Education, 216: 45-56.

[8]. Diem, E. \& Moyer, A .(2015) : Community and Public Health Nursing( Learning to make a difference through teamwork), $2^{\text {nd }}$ edition, Canadian Scholars" Press Inc. p. 278 .

[9]. Elgerjawy, M., Ouda, W., Adly, R., Tantawi, H. (2015): Effect of information technology based intervention on glycemic control of children suffering from diabetes in Gaza Strip, Egyptian Journal of Health Care, 2014 EJHC 5(2): 186.

[10]. Hakoama, M., \& Hakoyama, S. (2011): The impact of cell phone use on social networking and development among college students. American Association of Behavioural and Social Science; 5.

[11]. Ibrahiem, D. (2016): Effect of Health Educational Intervention to Faculty of Nursing Students about Mobile Phone Healthy Us, Doctorate thesis, Faculty of Nursing, Helwan University.

[12]. Institute of Medicine. (2011): Crossing the quality chasm: The IOM Health Care Quality Initiative [Announcement] Washington, DC: National Academies Press. Retrieved from http://www. iom.edu/Global/News\%20Announcements/Crossingthe-Quality-Chasm-The-IOM-Health-Care-Quality-Initiative.aspx.

[13]. Jiang, S., \& Beaudoin, C.E. (2016): Smoking Prevention in China: A Content Analysis of an Anti-Smoking Social Media Campaign. Journal of Health Communication; 21(7):755.

[14]. Kanwal, N., \& Archana, P. (2004): Internet Addiction in Students: A Cause of Concern. Cyber psychology \& behavior, 6(6): $653-656$.

[15]. King, A.L., Valença, A.M., Silva, A.C., Sancassiani, F., Machado, S., \& Nardi, A.E. (2014): "Nomophobia": impact of cell phone use interfering with symptoms and emotions of individuals with panic disorder compared with a control group. Clin Pract Epidemiol Ment Health.; 10:28-35.

[16]. Kuznekoff, J.H., \& Titsworth, S. (2013): "The impact of mobile phone usage on student learning," Communication Education, 62:233-252.

[17]. McManis, L., \& Gunnewing S. (2012): Finding the education in educational technology with early learners. Young Children; 67(3): 14-24

[18]. Merlo, L.J., Stone, A.M., \& Bibbey, A. (2013): Measuring problematic mobile phone use: development and preliminary psychometric properties of the pump scale. J Addict; 2013:912807.

[19]. Nehra, R., Kate, N., Grover, S., Khehra, N., \& Basu, D. (2012): Does the excessive use of mobile phones in young adults reflect an emerging behavioural addiction? J Postgrad Med Edu Res; 46(4):177-82.

[20]. North, D., Johnston, K., \& Ophoff, J. (2014): "The use of mobile phones by south african university students," Issues in Informing Science and Information Technology, 11.

[21]. Santosh, K., Suzanne, A.B., \& Andrew, E.B. (2009): Healthcare via cell phones: A systematic review telemedicine and ehealth, 15(3): 231-240

[22]. Shinde, M., \& Patel, S. (2014): Co-relation between "problematic internet use" and mental health in professional education students. International Journal of Science and Research (IJSR); 3(2): 194-202.

[23]. Thomée, S., Härenstam, A., \& Hagberg, A. (2011): Mobile phone use and stress, sleep disturbances, and symptoms of depression among young adults - a prospective cohort study, BMC Public Health. 11: 66

[24]. Titilayo, O. \& Okanlawon, F. (2014): Assessment of Mobile Health Nursing Intervention Knowledge among Community Health Nurses in Oyo State, Nigeria. Afr J Med Med Sci.; 43(Suppl 1): 147-155.

[25]. Wikipedia, (2016): Health Educational Program. Available at: https://en.wikipedia.org/wiki/Health_education

[26]. Wilkinson, O., Duncan, S., Pryor, J., \& Hodson, M. (2008): A feasibility study of home telemedicine. Journal of Telemed. Telecare; 14(4):182-185.

[27]. World Health Organization, (WHO), (2006): What effects do mobile phones have on people's health? Available at: http://www.euro.who.int/_data/assets/pdf_file/0006/74463/E89486.pdf

[28]. World Health Organization, (WHO), (2011): International Agency for Research on Cancer (IARC), classifies radiofrequency ele 